\title{
Transmissible Gastroenteritis
}

\author{
MECHANISMS RESPONSIBLE FOR DIARRHEA IN AN \\ ACUTE VIRAL ENTERITIS IN PIGLETS
}

\author{
D. G. Butler, D. G. Gall, M. H. Kelly, and J. R. Hamitton \\ From the Department of Pediatrics, University of Toronto and the Research \\ Institute, The Hospital for Sick Children, Toronto M5G 1X8 Ontario, Canada
}

\begin{abstract}
A B S T R A C T We studied 3-wk-old piglets $40 \mathrm{~h}$ after experimental infection with transmissible gastroenteritis (TGE) virus to identify the mechanisms of diarrhea in this disease and to better understand infectious diarrhea in humans. Using continuous segmental marker perfusion in four regions along the gut, we found significant increases in net intraluminal accumulation of water and electrolytes only in the proximal jejunum, the region infected by the virus. In this jejunal segment studied in vivo, unidirectional sodium flux, extracellular fluid (ECF) to lumen, significantly increased, lumen to ECF significantly decreased, compared with matchfed littermates. The standard perfusate rendered hypertonic by adding mannitol ( $450 \mathrm{mosmol} / \mathrm{kg}$ ), in the same segment of normal pigs, caused only an increase in ECF to lumen flux of sodium. TGE did not alter gross villous structure or intraluminal bacteria, bile salts, lactate, $\mathrm{pH}$, or osmolality. Epithelial cell migration was accelerated in the jejunum of infected pigs. Isolated in suspension, these cells from TGE pigs exhibited increased active and passive sodium efflux, cells from mannitol-perfused pigs exhibited only increased active sodium efflux. In this viral enteritis, altered sodium transport occurring in the jejunum, the region of the intestine infected appears to be associated with defective epithelial cell function. The precise nature of the abnormalities in sodium transport, their relationship to disturbances of transport of other solutes, and to virus epithelial cell interaction remain to be defined.
\end{abstract}

\section{INTRODUCTION}

To better understand acute infectious diarrhea in humans we investigated the mechanisms causing diarrhea

Received for publication 14 May 1973 and in revised form 29 October 1973. in transmissible gastroenteritis, a specific enteric viral infection of swine. This disease, caused by a Corona virus (1), is characterized by vomiting, diarrhea, and dehydration within $24 \mathrm{~h}$ of infection (2). Piglets infected at birth almost all die whereas those infected at 3 wk of age survive and their diarrhea subsides within 2 wk (3). The maximum effect of this disease is reported to be on the proximal small intestine where the virus infects mature mucosal epithelial cells (3-7). We had found that piglets infected at 3 wk of age had massive diarrhea with increased quantities and concentrations of sodium, potassium, and chloride in stools (8). We will describe controlled in vivo segmental perfusion studies (9) in infected piglets that identify the proximal jejunum as the region of major electrolyte and water loss and characterize sodium transport at that site. We will also describe in vitro experiments which support the hypothesis that disordered sodium transport plays an important role in the pathogenesis of this diarrhea.

\section{METHODS}

Litters of conventional piglets of the York breed were weaned at 2 wk of age, and at operation under general anaesthesia a triple lumen tube (TLT) ${ }^{1}$ was securely fixed in the bowel lumen via a fistula. TLT were constructed from polyvinyl tubing ( 8 french) so that the mixing and test segments were 10 and $30 \mathrm{~cm}$, respectively. After operation the piglets were placed in individual holding pens and fed reconstituted whole evaporated cows' milk. They convalesced for $1 \mathrm{wk}$ during which time they were trained to lie quietly when suspended in cloth slings. Experiments were begun on the 7th postoperative day when the piglets were fully recovered. Piglets to be infected were given orally $2 \mathrm{ml}$ of a virus suspension containing the Purdue

${ }^{1}$ Abbreviations used in this paper: ECF, extracellular fluid; PEG, polyethylene glycol; TGE, transmissible gastroenteritis; TLT, triple lumen tube. 
strain of transmissible gastroenteritis (TGE) virus prepared as a bacterial-free homogenate of whole intestinal mucosa (4). Infected piglets were isolated in a special facility.

Experiments. In the first series of experiments we measured net water and electrolyte flux by marker perfusion in four specific regions of the bowel. Piglets were then infected and $40 \mathrm{~h}$ later subjected to a second perfusion study. Simultaneously, identical studies were carried out on uninfected match-fed littermates. We studied 15 piglets intubated in the upper jejunum $30 \mathrm{~cm}$ beyond the ligament of Treitz; 5 intubated in the mid-jejunum $250 \mathrm{~cm}$ above the cecum; 5 intubated in the ileum $30 \mathrm{~cm}$ above the cecum, and 3 intubated in the colon. The perfusion solution contained $120 \mathrm{mM} \mathrm{Na}{ }^{+}, 40 \mathrm{mM} \mathrm{K} \mathrm{K}^{+}, 115 \mathrm{mM} \mathrm{Cl}^{-}, 45 \mathrm{mM}$ $\mathrm{HCO}_{3}^{-}, 20 \mathrm{mM}$ glucose, and as a nonabsorbable marker, polyethylene glycol 4,000 (PEG 4,000) $5 \mathrm{~g} /$ liter, giving an osmolality of $320 \mathrm{mosmol} / \mathrm{kg}$ water and $\mathrm{pH} 7.80$ at $37^{\circ} \mathrm{C}$. Preliminary studies had established that PEG 4,000 was a satisfactory marker in this model, that steady-state conditions existed in test segments after $60 \mathrm{~min}$ of continuous perfusion at $1.8 \mathrm{ml} / \mathrm{min}$ in small bowel and $7.5 \mathrm{ml} / \mathrm{min}$ in colon, and that transit times through test segments were 15 and $20 \mathrm{~min}$, respectively. Preceded by an 8-h fast and then a 1-h equilibration period, each perfusion study lasted $1 \frac{1}{4}$ h. Consecutive 15-min samples were collected by a staggered technique (9) from proximal and distal sampling sites of the TLT using controlled gravity flow into containers chilled at $4^{\circ} \mathrm{C}$. The collected juice was filtered at $10^{\circ} \mathrm{C}$ for $18 \mathrm{~h}$. Samples for glucose and lactate measurements were deproteinized with $0.6 \%$ perchloric acid and all juice was frozen at $-30^{\circ} \mathrm{C}$ until analyzed. The pigs were killed at the end of the second perfusion study. The location of the perfusion tube was identified and in each case it had not shifted from its inserted position. Tissue from the perfused segment was obtained by scraping the mucosa from a $15-\mathrm{cm}$ segment with a glass slide. This tissue was homogenized in buffered saline $(\mathrm{pH} 8.0)$ containing $20 \mathrm{mM}$ $\mathrm{Mg}^{++}$to yield a protein concentration of $8-12 \mu \mathrm{g} / \mathrm{ml}$ and analyzed for adenyl cyclase activity. These experiments identified the proximal jejunum as the region in which the major losses of water and electrolytes occurred.

A second series of experiments was designed to study sodium and water transport in the proximal jejunum in TGE in more detail. The piglets were prepared identically to those described above with TLT implanted in the proximal jejunum. However, for these experiments the litters were divided into three groups, infected and control as above, and an added group of normal uninfected piglets which were perfused with hypertonic mannitol (the perfusate described above to which we added mannitol, 23.5 $\mathrm{g} /$ liter giving an osmolality of $450 \mathrm{mosmol} / \mathrm{kg}$ water). In preliminary studies we had established that this degree of hypertonicity induced a net sodium flux across normal jejunum similar to that observed in TGE. As before, we measured net flux of water and electrolyte before and after infection (15 piglets), comparing our data with those from uninfected controls ( 6 piglets) and those receiving the hypertonic perfusion (13 piglets). In all animals we measured unidirectional sodium flux by adding a tracer dose of ${ }^{22} \mathrm{Na}(50 \mu \mathrm{Ci} /$ liter $)$ to the perfusion solution. We had determined that in this model reflux of ${ }^{22} \mathrm{Na}$ from ECF to the lumen of the test segment was insignificant. During these studies we also collected proximal jejunal juice for bacteriological studies and bile salt measurements, before and after infection. All piglets were killed after the post- infection perfusion study and the intestinal cells were isolated immediately from the perfused segments for measurement of sodium efflux rate constants. $2-\mathrm{cm}$ pieces of the perfused segments were immediately stapled on paraffin blocks, fixed in Suza's fixative for $24 \mathrm{~h}$, then transferred to $95 \%$ ethanol and processed routinely for staining with hematoxylin and eosin. For electron microscopy, jejunal mucosa was fixed in 3\% gluteraldehyde buffer, rinsed in buffer, postfixed in $1 \%$ osmium tetroxide in veronal acetate buffer, and embedded in epon. Sections were cut with a diamond knife, stained with uranyl acetate and lead citrate, and examined in a Philips EM 200 electron microscope (Philips Electronic Instruments, Mount Vernon, N. Y.)

Suspensions of isolated epithelial cells were prepared by everting $15-\mathrm{cm}$ lengths of the perfused segments of proximal jejunum over a spiral rod, immersing it in ice-cold buffered saline $\left(2 \mathrm{mM}\right.$ Tris $\mathrm{pH} 7.40$ at $\left.4^{\circ} \mathrm{C}\right)$, and subjecting it to high frequency, low amplitude vibration for $30 \mathrm{~min}$ as described by Levine and Weintraub (10). The cell pellet obtained by centrifuging this suspension at $50 \mathrm{~g}$ was washed twice in ice-cold buffered saline $(\mathrm{pH} 7.40$ at $4^{\circ} \mathrm{C}$ ) before measurements of $\mathrm{Na}^{+}$efflux were made. This technique isolates, almost exclusively, epithelial cells from the villi rather than the crypt cells.

In the third experiment the rate of jejunal epithelial cell migration on the villus was measured in normal and TGE infected 3-wk-old piglets. Four piglets from a litter of six were randomly chosen and each given a standard oral dose of TGE virus. The other two piglets were left as match-fed controls. $16 \mathrm{~h}$ after infection, each piglet was given a subcutaneous injection of tritiated thymidine at the rate of $0.3 \mu \mathrm{Ci} / \mathrm{g}$ body weight (sp act $18.4 \mathrm{Ci} / \mathrm{mM}$ ). 24 $\mathrm{h}$ postinfection, one control and two infected piglets were killed and at $40 \mathrm{~h}$ after infection, one control and two infected piglets were killed. From each animal, a $3-\mathrm{cm}$ length of intestine, starting $30 \mathrm{~cm}$ distal to the ligament of Treitz was opened along the mesenteric border, stapled flat on a paraffin block, serosal side down, placed in Bouin's fixative for $12 \mathrm{~h}$, and transferred to $70 \%$ alcohol. Tissue sections $4 \mu \mathrm{m}$ thick were cut and prepared for autoradiography, exposed for $1 \mathrm{mo}$ at $10^{\circ} \mathrm{C}$, and stained with hematoxylin and eosin. To determine migration rates of the epithelial cells, the distance from the base of the crypt to the foremost labeled cells was measured using a previously calibrated eyepiece. From the difference of the means of measurements made on piglets killed at 24 and $40 \mathrm{~h}$ a rate of migration over the $16 \mathrm{~h}$ interval was calculated.

Analytical techniques. Sodium and potassium were measured by flame spectrophotometry and chloride by titration using standard laboratory techniques. Osmolality was determined by freezing point depression, glucose by the glucose oxidase method (11), lactate using lactic dehydrogenase (Boehringer Mannheim Corp., New York), and PEG spectrophotometrically by the method of Hyden (12). We measured ${ }^{22} \mathrm{Na}$ activity in a Gamma Counter (Nuclear Chicago, Corp., Des Plaines, Ill.). Qualitative and semiquantitative measurements of bile salts in intestinal juice were made by thin-layer chromatography. We separated conjugated bile salts (glycocholate, glycodeoxycholate, glycochenodeoxycholate, taurocholate, taurodeoxycholate, taurochenodeoxycholate) using Kottke's solvent system (13) and free bile salts (cholate, deoxycholate, chenodeoxycholate) with Sundaram's solvent (14). All chromatographs were subjected to the same spray for color detection (15). Bacterial content of juice was estimated by direct examination of gram-stained specimens and quantitative counts 
TABLE I

Analyses of Variance Comparing Net Electrolyte and Water Fluxes and Mean Electrolyte Concentrations* in Proximal Jejunum of Normal and Infected Piglets and Normal Piglets Perfused with Hypertonic Solution (NH Piglets)

\begin{tabular}{|c|c|c|c|c|c|c|c|c|c|c|c|c|c|c|c|c|c|c|c|}
\hline & \multicolumn{4}{|c|}{$\mathrm{Na}^{+}, m M / h / c m$} & \multirow[b]{2}{*}[\mathrm{Na}^{+}]{} & \multicolumn{4}{|c|}{$\mathrm{H}_{2} \mathrm{O}, \mathrm{ml} / \mathrm{h} / \mathrm{cm}$} & \multicolumn{4}{|c|}{$\mathrm{Cl}^{-}, \mathrm{mM} / \mathrm{h} / \mathrm{cm}$} & \multirow[b]{2}{*}[\mathrm{Cl}^{-}]{} & \multicolumn{4}{|c|}{$\mathrm{K}^{-}, m M / h / c m$} & \multirow[b]{2}{*}[\mathrm{K}^{+}]{} \\
\hline & Mean & SD & $n$ & $P<$ & & Mean & SD & $n$ & $P<$ & Mean & SD & $n$ & $P<$ & & Mean & SD & $n$ & $P<$ & \\
\hline ontrol & +0.009 & \pm 0.049 & 28 & - & 0.125 & +0.153 & \pm 0.430 & 28 & - & +0.020 & \pm 0.058 & 28 & - & 0.121 & +0.029 & \pm 0.015 & 28 & - & 0.026 \\
\hline Infected & -0.119 & \pm 0.092 & 28 & 0.005 & 0.124 & -0.920 & \pm 0.752 & 28 & 0.005 & -0.104 & \pm 0.073 & 28 & 0.005 & 0.118 & +0.003 & \pm 0.013 & 27 & 0.01 & 0.027 \\
\hline NH & -0.105 & \pm 0.081 & 36 & 0.005 & 0.111 & -1.218 & \pm 0.980 & 36 & 0.005 & -0.106 & \pm 0.099 & 36 & 0.005 & 0.110 & +0.017 & \pm 0.019 & 36 & 0.05 & 0.025 \\
\hline
\end{tabular}

Positive values indicate net absorption out of intestinal lumen. Negative values indicate net secretion into lumen.

* Millimoles per milliliter.

made after $48 \mathrm{~h}$ and serial dilutions $\left(10^{-1}-10^{-5}\right)$ plated on blood agar, aerobically and anaerobically; MacConkey's agar, aerobically and Rogasa agar, anaerobically. Each light microscopic slide of jejunal mucosa was examined by one observer (Dr. Butler) unaware of whether the tissue was from an infected or uninfected piglet. A standard calibrated micrometer eyepiece was used to measure villous height and crypt depth. Epithelial cell morphology and round cell infiltration were also rated. Adenyl cyclase activity (basal and fluoride stimulated) was measured on whole mucosal homogenates (16). Optimal conditions for the assay in pig tissue had been determined in preliminary studies.

To measure sodium efflux rate constants in intestinal epithelial cells, approximately $0.5 \mathrm{ml}$ of packed cells was added to $3 \mathrm{ml}$ of either a medium containing $\mathrm{NaCl} 120$ $\mathrm{mM}$, Tris $\mathrm{HCl} 20 \mathrm{mM}, \mathrm{K}_{2} \mathrm{HPO}_{4} 3 \mathrm{mM}, \mathrm{MgCl}_{2} 1 \mathrm{mM}$ $\mathrm{CaCl}_{2} 1 \mathrm{mM}$, glucose $10 \mathrm{mM}$, bovine serum albumin 1 $\mathrm{mg} / \mathrm{ml},{ }^{22} \mathrm{Na} 2.5 \mu \mathrm{g} / \mathrm{ml}$ (osmolality $290 \mathrm{mosmol} / \mathrm{kg}$ water, $\mathrm{pH} 7.40$ at $37^{\circ} \mathrm{C}$ ) or to the same medium to which ouabain $10^{-8} \mathrm{M}$ had been added. The mixtures were incubated at $37^{\circ} \mathrm{C}$ for $30 \mathrm{~min}$ in a Dubnoff metabolic shaker and immediately centrifuged for $1 \mathrm{~min}$ at $4^{\circ} \mathrm{C}$, and washed twice in ice-cold buffered isotonic $\mathrm{MgCl}_{2}$ (110 $\mathrm{mM} \mathrm{MgCl}_{2}, 2$ $\mathrm{mM}$ Tris, $\mathrm{pH}$ 7.40). While maintaining dilution at $1: 30$ the cells were resuspended in tracer-free flux medium with or without ouabain. The sodium efflux was ascertained by measuring the rate of appearance of ${ }^{22} \mathrm{Na}$ in the medium as described for $\mathrm{Na}^{+}$efflux from the red blood cells (17) and expressed as the total sodium efflux constant $/ \mathrm{h}$ $\left({ }^{\circ} \mathrm{K}^{T} \mathrm{Na}^{+}\right)$and the passive sodium efflux constant/h $\left({ }^{\circ} \mathrm{K}^{P} \mathrm{Na}^{+}\right)(18)$. The passive efflux rate constant is defined as the ouabain-insensitive portion of the total efflux rate constant remaining after maximal inhibition. Optimal con- ditions for both cell isolation (temperature, vibration time, and centrifugal force) and $\mathrm{Na}^{+}$efflux (duration and temperature of loading, composition of solution to remove excess isotope, and ouabain concentration required for maximum inhibition) had been determined in preliminary studies. The integrity of the isolated cells was evaluated by trypan blue exclusion (19) and we demonstrated that $80 \%$ excluded trypan blue up to $3 \mathrm{~h}$ after isolation. Sodium efflux constants determined on cell suspensions from control and experimental groups were stable up to $3 \mathrm{~h}$ after isolation and were independent of the number of cells incubated.

Calculations. Standard formulas were used to calculate the net fluxes of water and electrolyte (9) and the unidirectional $\mathrm{Na}^{+}$fluxes (20) across the test segment of bowel in vivo. We compared means of the changes observed in these flux data between the two perfusion studies in control and test groups by an analysis of variance. When significant " $F$ " values occurred the means were ranked using Scheffe's method for multiple comparisons (21). Data from the in vitro experiments were compared using standard Student's $t$ tests.

\section{RESULTS}

In vivo net flux studies. The proximal jejunum was the only site of significant net electrolyte and water loss after infection with the virus. Table I shows the analyses of variance between net fluxes in the proximal jejunum of the three study groups, control, infected, and those perfused with a hypertonic solution ( $\mathrm{NH}$ piglets). In infected piglets and $\mathrm{NH}$ piglets the reversal in the net fluxes of $\mathrm{Na}^{+}, \mathrm{Cl}^{-}$, and water was significant $(P<$

TABLE II

Analyses of Variance Comparing Flow Rate, Osmolality, and $p H$ Entering and Leaving Proximal Jejunal Test Segment during Continuous Segmental Perfusion in Control and Infected Piglets and Normal Piglets Perfused with Hypertonic Solution (NH Piglets)

\begin{tabular}{|c|c|c|c|c|c|c|c|c|c|c|c|c|c|c|c|c|c|c|c|c|c|c|c|c|}
\hline & \multicolumn{8}{|c|}{ Flow, $m l / \min$} & \multicolumn{8}{|c|}{ Osmolality, mosmol/kg water } & \multicolumn{8}{|c|}{$\mathrm{pH}$} \\
\hline & \multicolumn{4}{|c|}{ Entering } & \multicolumn{4}{|c|}{ Leaving } & \multicolumn{4}{|c|}{ Entering } & \multicolumn{4}{|c|}{ Leaving } & \multicolumn{4}{|c|}{ Entering } & \multicolumn{4}{|c|}{ Leaving } \\
\hline & Mean & SD & $n$ & $P<$ & Mean & SD & $n$ & $P<$ & Mean & SD & $\boldsymbol{n}$ & $P<$ & Mean & SD & $n$ & $P<$ & Mean & SD & $n$ & $P<$ & Mean & SD & $n$ & $P<$ \\
\hline Control & 1.70 & \pm 0.50 & 25 & - & 1.67 & \pm 0.63 & 25 & - & 312 & \pm 7 & 25 & - & 303 & \pm 13 & 25 & 一 & 8.57 & \pm 0.30 & 25 & - & 8.58 & \pm 0.35 & 25 & - \\
\hline $\begin{array}{l}\text { Infected } \\
\text { Hyper- }\end{array}$ & 1.51 & \pm 0.29 & 23 & 0.05 & 1.95 & \pm 0.49 & 23 & 0.01 & 312 & \pm 9 & 23 & 一 & 309 & \pm 17 & 20 & - & 8.69 & \pm 0.19 & 23 & - & 8.53 & \pm 0.44 & 22 & - \\
\hline tonic & 2.18 & \pm 0.50 & 31 & 0.01 & 2.79 & \pm 0.63 & 31 & 0.005 & 371 & \pm 18 & 31 & 0.005 & 329 & \pm 15 & 31 & 0.005 & 8.35 & \pm 0.42 & 31 & 0.01 & 8.21 & \pm 0.47 & 31 & 0.01 \\
\hline
\end{tabular}

Mechanisms for Diarrhea in an Acute Viral Enteritis 
TABLE III

Analyses of Variance Comparing Net Fluxes of Electrolytes, Water in Mid-Small Bowel, Distal Ileum, and Colon in Piglets before and $40 \mathrm{~h}$ after Infection (TGE)

\begin{tabular}{|c|c|c|c|c|c|c|c|c|c|c|c|c|c|}
\hline & & \multicolumn{3}{|c|}{$\mathrm{Na}^{+}, m M / h / c m$} & \multicolumn{3}{|c|}{$\mathrm{H}_{2} \mathrm{O}, \mathrm{ml} / \mathrm{h} / \mathrm{cm}$} & \multicolumn{3}{|c|}{$\mathrm{Cl}^{-}, m M / h / c m$} & \multicolumn{3}{|c|}{$\mathrm{K}^{+}, m M / h / c m$} \\
\hline & . & Mean & SD & $n$ & Mean & SD & $n$ & Mean & SD & $n$ & Mean & SD & $n$ \\
\hline \multirow[t]{2}{*}{ Mid-small bowel } & Control & +0.012 & \pm 0.026 & 8 & +0.085 & \pm 0.077 & 8 & +0.019 & \pm 0.014 & 8 & +0.015 & \pm 0.008 & 8 \\
\hline & Infected & -0.033 & \pm 0.017 & 8 & -0.312 & \pm 0.175 & 8 & -0.016 & \pm 0.013 & 8 & +0.008 & \pm 0.007 & 8 \\
\hline \multirow[t]{2}{*}{ Distal ileum } & Control & +0.009 & \pm 0.060 & 12 & +0.043 & \pm 0.530 & 12 & +0.030 & \pm 0.045 & 12 & +0.019 & \pm 0.019 & 12 \\
\hline & Infected & -0.043 & \pm 0.054 & 12 & -0.361 & \pm 0.453 & 12 & +0.003 & \pm 0.037 & 12 & +0.010 & \pm 0.006 & 12 \\
\hline \multirow[t]{2}{*}{ Colon } & Control & +3.05 & \pm 4.24 & 6 & +2.18 & \pm 4.95 & 6 & +4.59 & \pm 1.09 & 6 & +1.31 & \pm 1.25 & 6 \\
\hline & Infected & +6.68 & \pm 2.16 & 6 & +6.82 & \pm 9.17 & 6 & +4.79 & \pm 1.70 & 6 & +1.20 & \pm 0.68 & 6 \\
\hline
\end{tabular}

Positive values indicate net absorption out of intestinal lumen. Negative values indicate net secretion into lumen.

0.005 ) as was the decrease in the net flux of potassium. Whether caused by infection or hypertonic perfusion, the induced net losses of $\mathrm{Na}^{+}$and $\mathrm{Cl}^{-}$into the lumen were similar. However, compared with infected pigs, hypertonic perfusion produced a significantly greater net loss of water into the intestinal lumen $(P<0.01)$ and a significantly greater net $\mathrm{K}^{+}$flux out of the lumen $(P<$ $0.05)$. Table II shows that the flow rate entering the test segment was lowest in infected piglets, intermediate in the controls, and highest in the NH piglets. The flow rate leaving the test segment in infected piglets was significantly greater than in control piglets and significantly less than in the normal piglets given the hypertonic solution. Osmolality at either end of the test segment was similar for infected and control piglets, but as expected, it was significantly greater in $\mathrm{NH}$ piglets (Table II). The $\mathrm{pH}$ of intestinal contents did not differ between groups (Table II). Net flux data from studies on the more distal segments are summarized in Table III. Infection produced no significant effect.

In vivo unidirectional sodium flux studies. The combined results of the unidirectional sodium flux studies between lumen and ECF of proximal jejunum in normal and infected piglets and $\mathrm{NH}$ piglets are listed in Table IV. Unidirectional sodium flux from lumen to ECF $\left(\phi^{\mathrm{N} a} \mathrm{~L} \rightarrow \mathrm{ECF}\right)$ in infected piglets was significantly decreased $(P<0.005)$; the opposite unidirectional so- dium flux $\left(\phi^{\mathrm{Na}+} \mathrm{ECF} \rightarrow \mathrm{L}\right)$ in infected pigs was significantly greater than that observed in controls $(P<0.01)$. The $\phi^{\mathrm{Na}+} \mathrm{L} \rightarrow \mathrm{ECF}$ in the $\mathrm{NH}$ piglets was similar to control values but the $\phi^{\mathrm{Na}+\mathrm{ECF}} \rightarrow \mathrm{L}$ was significantly greater $(P<0.005)$. In $\mathrm{NH}$ piglets $\phi^{\mathrm{Na}+} \mathrm{ECF} \rightarrow \mathrm{L}$ was significantly greater than in infected piglets $(P<0.01)$. Thus we observed changes in both unidirectional sodium fluxes after infection whereas only the $\phi^{\mathrm{Na}+} \mathrm{ECF} \rightarrow \mathrm{L}$ was altered during hypertonic perfusion.

The numbers and types of bacterial organisms present in the proximal intestinal lumen were not altered by the viral infection (Table $\mathrm{V}$ ). Lactate concentrations $\left(\times 10^{-4} \mathrm{mM} / \mathrm{ml}\right.$ ) entering, $1.77 \pm 0.82$ (mean $\left.\pm \mathrm{SD}\right)$ and leaving, $1.94 \pm 0.99$ the proximal jejunal segment measured in 8 piglets $40 \mathrm{~h}$ after infection did not differ significantly from concentrations measured before infection, $1.65 \pm 0.68$ and $1.96 \pm 0.40$, respectively. Bile salt concentrations $(\mathrm{mM} /$ liter $)$ in juice from intubated proximal jejuna after infection, both conjugated $0.68 \pm$ 0.61 and free, $1.21 \pm 0.25$ also did not differ signficantly from control data $0.78 \pm 0.44$ and $1.46 \pm 0.38$. There was a preponderance of free bile salts in the juice of both groups.

Intestinal morphology. By light microscopy there were no significant abnormalities in the dimensions of villi or crypts in infected piglets. The cells at the tips of villi appeared cuboidal rather than columnar as one

TABLE IV

Analyses of Variance Comparing Unidirectional Sodium Fluxes between Intestinal Lumen and Extracellular Fluid in Proximal Jejunum of Control and Infected Piglets and Normal Piglets Perfused with Hypertonic Solution (NH Piglets)

\begin{tabular}{|c|c|c|c|c|c|c|c|c|}
\hline \multirow[b]{3}{*}{ Comparison } & \multicolumn{8}{|c|}{ Direction } \\
\hline & \multicolumn{4}{|c|}{$\mathrm{L} \rightarrow \mathrm{ECF}, \mathrm{mM} / \mathrm{h} / \mathrm{cm}$} & \multicolumn{4}{|c|}{$\mathrm{ECF} \rightarrow \mathrm{L}, m M / h / c m$} \\
\hline & Mean & SD & $n$ & $P<$ & Mean & SD & $n$ & $P<$ \\
\hline Control & 0.133 & \pm 0.090 & 13 & 一 & 0.127 & \pm 0.079 & 13 & - \\
\hline Infected & 0.071 & \pm 0.049 & 11 & 0.005 & 0.192 & \pm 0.101 & 11 & 0.01 \\
\hline NH & 0.147 & \pm 0.075 & 13 & 一 & 0.260 & \pm 0.104 & 13 & 0.005 \\
\hline
\end{tabular}


TABLE V

Colony Counts* and Bacterial Species Isolated per Milliliters Intestinal Juice Collected from Intubated Proximal Jejuna of Piglets before and $40 \mathrm{~h}$ after Infection with Transmissible Gastroenteritis Virus

\begin{tabular}{|c|c|c|c|c|c|c|c|c|c|}
\hline \multirow[b]{2}{*}{ Medium } & \multicolumn{4}{|c|}{ Control (preinfection) } & \multicolumn{5}{|c|}{ Infected } \\
\hline & Mean & SD & $n$ & Species & Mean & SD & $n$ & $P<$ & Species \\
\hline $\begin{array}{l}\text { Blood agar } \\
\text { (Aerobic) }\end{array}$ & 125 & \pm 136 & 5 & $\begin{array}{l}\text { E. coli } \\
\text { Proteus } \\
\text { Hemolytic }\end{array}$ & 111 & \pm 52 & 5 & - & $\begin{array}{l}\text { E. coli } \\
\text { Proteus }\end{array}$ \\
\hline $\begin{array}{l}\text { Blood agar } \\
\text { (Anaerobic) }\end{array}$ & 134 & \pm 132 & 5 & E. coli & 129 & \pm 60 & 5 & 一 & E. coli \\
\hline $\begin{array}{l}\text { MacConkey's agar } \\
\text { (Aerobic) }\end{array}$ & 157 & \pm 145 & 5 & $\begin{array}{l}\text { E. coli } \\
\text { Proteus }\end{array}$ & 96 & \pm 35 & 5 & 一 & $\begin{array}{l}\text { E. coli } \\
\text { Proteus }\end{array}$ \\
\hline $\begin{array}{l}\text { Rogassa agar } \\
\text { (Anaerobic) }\end{array}$ & \multicolumn{4}{|c|}{$\begin{array}{l}\text { Very large numbers of lacto- } \\
\text { bacilli too fine to count. } \\
\text { However, no growth at } 10^{-6} \\
\text { dilution. }\end{array}$} & \multicolumn{5}{|c|}{$\begin{array}{l}\text { Very large numbers of lacto- } \\
\text { bacilli too fine to count. } \\
\text { However, no growth at } 10^{-6} \\
\text { dilution. }\end{array}$} \\
\hline
\end{tabular}

$* 10^{5}$.

sees in the normal. By electron microscopy, various changes were observed in some villous absorptive cells whereas others retained normal morphology (Figs. 1 and 2). The microvilli were shorter and less densely packed than in the normal cell. The filaments of the core of most microvilli and of the terminal web were less defined. In the apical cytoplasm, organelles were fewer and less well defined; some dilation and vesiculation was observed in the endoplasmic reticulum. Separation of the plications of lateral cell membrane was observed between adjacent cells on many villi but junctional complexes appeared intact.

Neither the length of jejunal villi in control piglets $(258 \pm 28 \mu \mathrm{m})$ and infected piglets $(237 \pm 69 \mu \mathrm{m})$ or crypt depth in control piglets $(226 \pm 15 \mu \mathrm{m})$ and infected piglets $(216 \pm 34 \mu \mathrm{m})$ were significantly different. However, jejunal epithelial cells migrated along villi of control piglets at a rate of $13 \mu \mathrm{m} / \mathrm{h}$ compared to a rate of $20 \mu \mathrm{m} / \mathrm{h}$ in infected piglets. At these rates the intestinal mucosa in control and infected piglets would be renewed in approximately 38 and $23 \mathrm{~h}$, respectively.

In vitro studies. Adenyl cyclase activity (basal or fluoride stimulated) in small or large intestine was unchanged after infection (Table VI).

The results of our in vitro studies on sodium efflux from isolated epithelial cells are listed in Table VII. Cells from infected piglets showed a significantly greater passive (ouabain-insensitive) $\mathrm{Na}^{+}$efflux constant $(P<$ $0.01)$ and total $\mathrm{Na}^{+}$efflux constant $(P<0.005)$ than cells from controls. The passive $\mathrm{Na}^{+}$efflux constant was unchanged in cells obtained from $\mathrm{NH}$ piglets whereas the total $\mathrm{Na}^{+}$efflux constant was significantly increased $(P<0.005)$. The passive $\mathrm{Na}^{+}$efflux constant for cells obtained from infected piglets was significantly greater than in cells from $\mathrm{NH}$ piglets $(P<0.005)$ whereas the total $\mathrm{Na}^{+}$efflux constants were similar.

\section{DISCUSSION}

Our studies have identified the proximal jejunum as the major site of electrolyte and water secretion in TGE. Since no compensatory mechanisms were detected in more distal intestinal segments, secretion in the upper intestine must have contributed substantially to the diarrhea observed. The experiments reported have been concerned primarily with the relationship between disordered sodium transport in the upper intestine and TGE diarrhea. We recognize that additional intestinal

TABLE VI

Adenyl Cyclase Activity, Basal and Fluoride Stimulated in Whole Mucosal Homogenates from Control Piglets and Piglets $40 \mathrm{~h}$ after Infection

\begin{tabular}{|c|c|c|c|c|c|c|c|}
\hline \multirow{2}{*}{$\begin{array}{l}\text { Intestinal } \\
\text { segment }\end{array}$} & & \multicolumn{3}{|c|}{ Control } & \multicolumn{3}{|c|}{ Infected (TGE) } \\
\hline & & Mean & SD & $n$ & Mean & SD & $n$ \\
\hline Proximal jejunum & $\begin{array}{l}\text { Basal } \\
\text { Fluoride }\end{array}$ & $\begin{array}{l}153 \\
711\end{array}$ & $\begin{array}{r}8 \\
97\end{array}$ & $\begin{array}{l}6 \\
6\end{array}$ & $\begin{array}{l}120 \\
605\end{array}$ & $\begin{array}{l}12 \\
71\end{array}$ & $\begin{array}{l}10 \\
10\end{array}$ \\
\hline $\begin{array}{l}\text { Mid-small } \\
\text { intestine }\end{array}$ & $\begin{array}{l}\text { Basal } \\
\text { Fluoride }\end{array}$ & $\begin{array}{l}113 \\
669\end{array}$ & $\begin{array}{l}17 \\
40\end{array}$ & $\begin{array}{l}6 \\
6\end{array}$ & $\begin{array}{l}115 \\
810\end{array}$ & $\begin{array}{l}11 \\
87\end{array}$ & $\begin{array}{l}10 \\
10\end{array}$ \\
\hline Distal ileum & $\begin{array}{l}\text { Basal } \\
\text { Fluoride }\end{array}$ & $\begin{array}{l}118 \\
600\end{array}$ & $\begin{array}{l}24 \\
63\end{array}$ & $\begin{array}{l}6 \\
6\end{array}$ & $\begin{array}{l}112 \\
744\end{array}$ & $\begin{array}{l}14 \\
57\end{array}$ & $\begin{array}{l}10 \\
10\end{array}$ \\
\hline Colon & $\begin{array}{l}\text { Basal } \\
\text { Fluoride }\end{array}$ & $\begin{array}{l}187 \\
869\end{array}$ & $\begin{array}{l}25 \\
40\end{array}$ & $\begin{array}{l}6 \\
6\end{array}$ & $\begin{array}{l}149 \\
845\end{array}$ & $\begin{array}{l}20 \\
61\end{array}$ & $\begin{array}{l}10 \\
10\end{array}$ \\
\hline
\end{tabular}

* Micromoles CAMP per milligrams protein. 


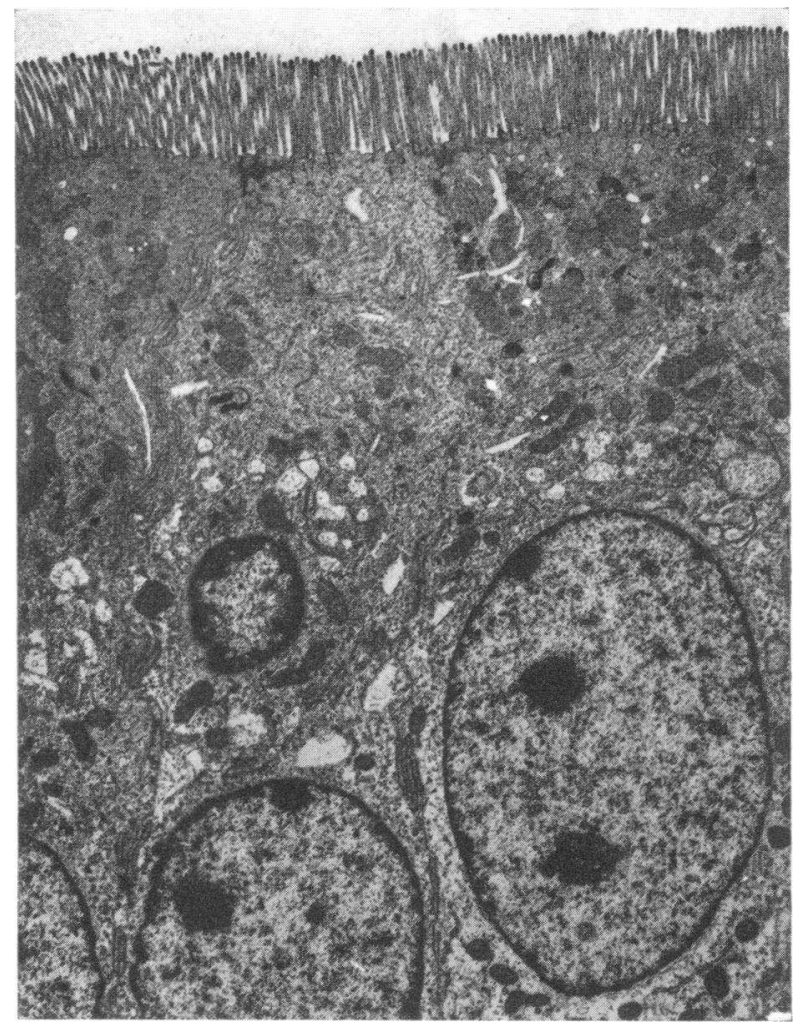

Figure 1 Electron micrograph, epithelial cells from lateral wall of jejunal villus of control piglet. Note long regular microvilli. Magnification $\times 5,400$.

transport processes may be affected by the disease, some of which may influence water and sodium transport.

The large net sodium flux into the jejunal lumen in TGE was mediated by a decreased $\phi^{\mathrm{Na}+} \mathrm{L} \rightarrow \mathrm{ECF}$ and an increased $\phi^{\mathrm{Na}+\mathrm{ECF}} \rightarrow \mathrm{L}$. Whatever the mechanisms causing these abnormalities, they differ significantly from those occurring in osmotically induced diarrhea. Perfusion of the upper jejunum with hypertonic mannitol caused a net sodium movement into the lumen similar to

TABLE VII

Comparison of Passive and Total Sodium Effux Constants Determined on Epithelial Cells Isolated from Proximal Jejuna of Control and Infected Piglets and Normal Piglets Perfused with the Hypertonic Solution (NH Piglets)

\begin{tabular}{|c|c|c|c|c|c|c|c|c|}
\hline \multirow{3}{*}{$\begin{array}{l}\text { Com- } \\
\text { parison }\end{array}$} & \multicolumn{8}{|c|}{ Sodium efflux corstant, $h^{-1}$} \\
\hline & \multicolumn{4}{|c|}{ Passive } & \multicolumn{4}{|c|}{ Total } \\
\hline & Mean & SD & $n$ & $P<$ & Mean & SD & $n$ & $P<$ \\
\hline Control & 3.11 & \pm 1.27 & 35 & - & 7.16 & \pm 1.78 & 27 & - \\
\hline Infected & 4.36 & \pm 1.21 & 30 & 0.01 & 13.80 & \pm 1.69 & 10 & 0.005 \\
\hline $\mathrm{NH}$ & 3.01 & \pm 1.32 & 28 & - & 12.29 & \pm 4.59 & 23 & 0.005 \\
\hline
\end{tabular}

that seen in TGE, but did not affect the undirectional lumen to ECF flux. Several factors may have affected $\phi^{\mathrm{Na}+} \mathrm{L} \rightarrow \mathrm{ECF}$ in TGE and our data provide little insight into the location and precise nature of the defect. Apparently, because of the relatively low glucose concentration in our perfusate, the defect was identified with virtually no glucose perfusing the test segment. One clue to a possible factor of importance comes from our electron microscopic studies. They showed spotty shortening and sparsity of microvilli at the luminal surface, a finding that would reduce absorptive surface area and one that was predicted by our earlier observations of decreased activity of some brush border enzymes (8). Our data showed that the increased $\phi^{\mathrm{Na}+\mathrm{ECF}} \rightarrow \mathrm{L}$ in $\mathrm{TGE}$ similar to that seen during hypertonic perfusion could not be attributed to increased concentration of intraluminal solutes such as sugars or organic acid anions. Our earlier study also suggested the TGE diarrhea is not an osmotic diarrhea (8). The route for the excessive flow of sodium into the lumen could have been intercellular, transcellular, or both (22). The marked abnormalities in sodium efflux in isolated

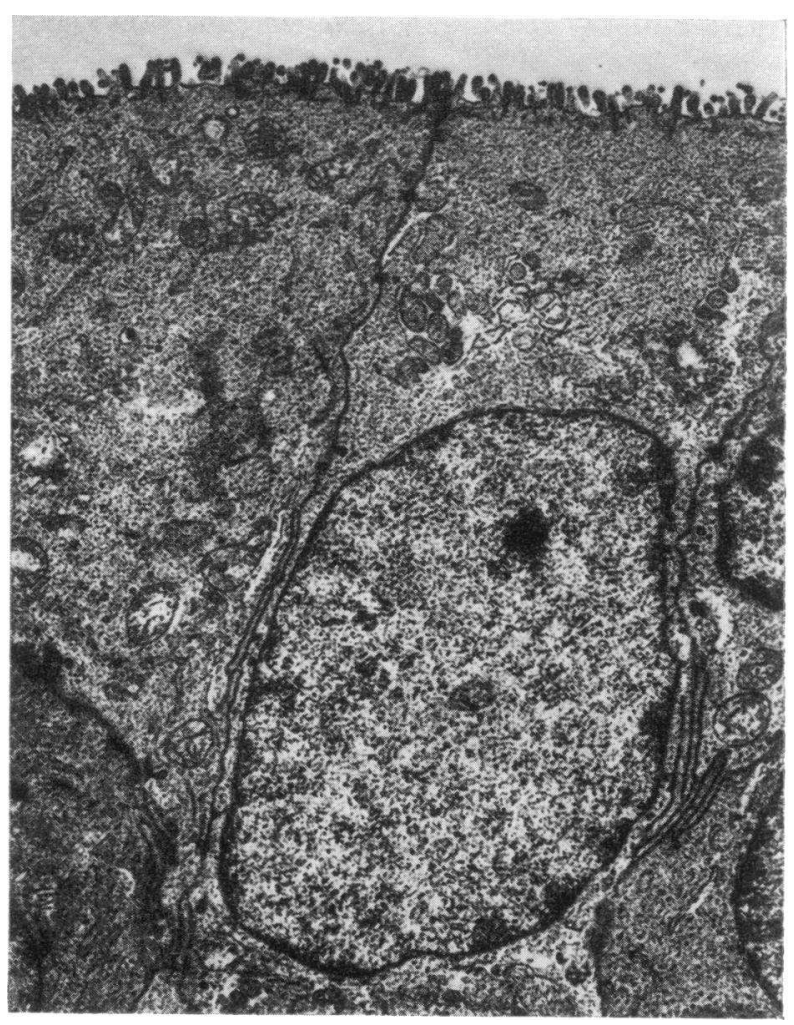

FIGURE 2 Electron micrograph, jejunal epithelial cells from TGE-infected piglet, demonstrating the most extensive ultrastructural abnormalities found. Sample site comparable with that seen in Fig. 1. Note shortened sparse microvilli. Magnification $\times 8,000$.

1340 D. G. Butler, D. G. Gall, M. H. Kelly, and J. R. Hamilton 
epithelial cells from infected pigs, studied under conditions identical to those used for controls, strongly suggest that cellular factors were contributory. These cellular factors are apparently not specific for TGE since hypertonic perfusion, to our surprise, induced a similar abnormality of total efflux. The factors causing this abnormality in response to mannitol may differ from TGE particularly since after mannitol passive efflux was unaffected. The abnormality of passive efflux observed in cells from infected pigs suggests increased cell membrane permeability. In TGE, unlike cholera (23) adenyl cyclase activity stimulation was not a factor in inducing a secretory state in the intestinal epithelium.

We attributed the observed abnormalities of intestinal function to a direct response to the viral infection. In the lumen of the proximal test segment, bacterial flora did not differ from controls. Bile salts might have been altered by abnormal flora (9) and when altered might have disturbed sodium transport (24). Although there was a preponderance of free bile salts in both infected and control pigs, the study groups did not differ significantly. The upper jejunum, the region known to be infected in TGE (5) is also the region most severely affected functionally. In planning future exploration of this specific viral enteritis, it is useful to speculate on the possible relationship between virus, epithelial cell interaction, and intestinal transport. The TGE virus infects primarily mature cells on tips of jejunal villi (6). We and others have shown that after infected cells are shed, they are replaced by cells migrating from the crypts at an accelerated rate (25). In our pigs, studied $40 \mathrm{~h}$ after infection, we were assessing an epithelial surface clothed by cells rapidly conscripted from the crypts and probably not infected by virus. In their haste to repair, do these cells retain the relatively undifferentiated state they possess in the crypts? Our microscopic studies and those in the literature suggest they do (6, $26)$. If in fact they do, our finding of marked sodium secretion in TGE is in keeping with the current hypothesis that crypt cells, unlike mature cells on villi are normally secretory (27). Obviously, may questions are raised by our data: many remain unanswered. Future studies of this specific viral enteritis should greatly improve our understanding of a major health problem in infants and children, acute viral gastroenteritis.

\section{ACKNOWLEDGMENTS}

The authors wish to thank Dr. E. O. Haelterman, Purdue University for supplying the virus used in these studies and Dr. J. M. Sturgess, The Research Institute, The Hospital for Sick Children, Toronto, for conducting the electron microscopic studies. We are grateful to Miss J. Bell, Mr. K. Wilson, Mr. M. Baker-Pierce, Mr. M. Khan, Mr. W. Wilson, and Mr. T. Ewart for their technical assistance.
The research was supported by grants from the Pathfinder Foundation and the Medical Research Council of Canada.

\section{REFERENCES}

1. Tajima, M. 1970. Morphology of transmissible gastroenteritis virus of pigs. A possible member of coronaviruses. Arch. Gesamte Virusforsch. 29: 105.

2. Haelterman, E. O., and B. E. Hooper. 1967. Transmissible gastroenteritis of swine as a model for the study of enteric disease. Gastroenterology. 53: 109.

3. Haelterman, E. O. 1962. Epidemiological studies of transmissible gastroenteritis of swine. Proceedings of the 66th Annual Meeting of the U. S. Live Stock Symposium. 305.

4. Hooper, B. E., and E. O. Haelterman. 1966. Growth of transmissible gastroenteritis virus in young pigs. $\mathrm{Am}$. J. Vet. Res. $27: 286$.

5. Pensaert, M., E. O. Haelterman, and T. Burnstein. 1970. Transmissible gastroenteritis of swine: virus-intestinal cell interactions. I. Immunofluorescence, histopathology and virus production in the small intestine through the course of infection. Arch. Gesamte Virusforsch. $31: 321$.

6. Pensaert, M., E. O. Haelterman, and E. J. Hinsman. 1970. Transmissible gastroenteritis of swine: virusintestinal cell interactions. II. Electron microscopy of the epithelium in isolated jejunal loops. Arch. Gesamte Virusforsch. $31: 335$.

7. Hooper, B. E., and E. O. Haelterman. 1969. Lesions of the gastrointestinal tract of pigs infected with transmissible gastroenteritis. Can. J. Comp. Med. 33: 29.

8. Kelly, M., D. G. Butler, and J. R. Hamilton. 1972. Transmissible gastroenteritis in piglets: a model of infantile viral diarrhea. J. Pediatr. 80: 925.

9. Whalen, G. E., J. A. Harris, J. E. Geenen, and K. H. Soergel. 1966. Sodium and water absorption from the human small intestine: the accuracy of the perfusion method. Gastroenterology. 51: 975.

10. Levine, P. H., and L. R. Weintraub. 1970. Preparation of suspensions of small bowel mucosal epithelial cells. J. Lab. Clin. Med. 75: 1026.

11. Sols, A., and G. de la Fuente. 1961. Hexokinase and other enzymes of sugar metabolism in the intestine. Methods Med. Res. 9: 302.

12. Hyden, S. 1956. A turbidometric method for the determination of the higher polyethylene glycols in biological materials. Upsala K. Lantbr. Annaler. 22: 139.

13. Kottke, B. A., J. Wollenweber, and C. A. Owen, Jr. 1966. Quantitative thin-layer chromatography of free and conjugated cholic acid in human bile and duodenal contents. J. Chromatogr. $21: 439$.

14. Sundaram, G. S., H. Singh, and H. S. Sodhi. 1971. Thin-layer chromatographic separation of chenodeoxycholic and deoxycholic acids. Clin. Chim. Acta. 34: 425.

15. Sundaram, G. S., and H. S. Sodhi. 1971. Colour detection of bile acids in thin-layer chromatography. $J$. Chromatogr. $61: 370$.

16. Krishna, G., B. Weiss, and B. B. Brodie. 1968. A simple, sensitive method for the assay of adenyl cyclase. J. Pharmacol. Exp. Ther. 163: 379.

17. Sachs, J. R., and L. G. Welt. 1967. The concentration 
dependence of active potassium transport in the human red blood cell. J. Clin. Invest. 46: 65.

18. Hoffman, J. F. 1962. The active transport of sodium by ghosts of human red blood cells. J. Gen. Physiol. 45 : 837.

19. Hanks, J. H., and J. H. Wallace. 1958. Determination of cell viability. Proc. Soc. Exp. Biol. Med. 98: 188.

20. Soergel, K. H., G. E. Whalen, and J. A. Harris. 1968. Passive movement of water and sodium across the human small intestinal mucosa. J. Appl. Physiol. 24: 40.

21. Cochran, W. G., and C. I. Bliss. 1967. Analysis of variance. Workshop Conference on Statistics in Endocrinology, Endicott House. J. W. McArthur and T. H. Coltan, editors. The M.I.T. Press, Cambridge, Mass. 57.

22. Frizzell, R. A., and S. G. Schultz. 1972. Ionic conductances of extracellular shunt pathway in rabbit ileum: influence of shunt on transmural sodium trans- port and electrical potential differences. J. Gen. Physiol. $59: 318$.

23. Field, M. 1971. Intestinal secretion: effect of cyclic AMP and its role in cholera. N. Engl. J. Med. 284: 1137.

24. Phillips, S. F. 1972. Diarrhea : a current view of the pathophysiology. Gastroenterology. 63: 495.

25. Moon, H. W., J. O. Norman, and G. Lambert. 1973. Age dependent resistance to transmissible gastroenteritis of swine (TGE). 1. Clinical signs and some mucosal dimensions in small intestine. Can. J. Comp. Med. 37 : 157.

26. Thake, D. C. 1968. Jejunal epithelium in transmissible gastroenteritis of swine. An electron microscopic and histochemical study. Am. J. Pathol. 53: 149.

27. Hendrix, T. R., and T. M. Bayless. 1970. Digestion: intestinal secretion. Annu. Rev. Physiol. 32: 139. 